\section{Britain's doctors in legal wrangle over confidentiality of records}

\section{London}

BRITAIN's medical profession is embroiled in the debate over the ethics and legality of withholding information from patients. Tests to determine the health of fetuses and others to identify AIDS (acquired immune deficiency syndrome) carriers has highlighted deficiences in British medical law.

The fetal test debate was originally provoked by a report from India of concern over the "steady increase in the incidence of female feticide", brought about by abortions inspired by information derived from amniocentesis testing (Nature 324, $202 ; 1986)$. The controversy continued with correspondence, in response to the Indian report (Nature 325, 190; 1987), from British cytogeneticists who have been withholding sex information culled from amniocentesis.

The debate has been reopened by the council of the Association of Clinical Cytogeneticists, which has become increasingly concerned over the potential misuse of amniocentesis data. Some members of the association have advocated withholding fetal sex details from parents who may demand abortion if the fetus is of the 'wrong' sex.

Last week, the council sought to determine the scale of the problem. Such evidence as could be acquired was 'anecdotal' and the association has been unable to issue definite guidelines. The full legal implications of withholding information from patients are to be investigated; in the meantime, the guidelines will be those agreed between "each regional laboratory and regional clinical colleagues".

While the UK Abortion Act theoretically does not allow the abortion of a fetus on the grounds of unwanted sex, health authorities have become increasingly concerned that the problems of India may be repeated in Britain, particularly among certain ethnic groups. Because of the scale of the problem in India - in a recent study of 8,000 abortions, 7,997 fetuses were female - new legislation is being drafted to restrict the practice of amniocentesis and other methods of determining fetal sex.

The screening of all hospital patients for the AIDS virus has raised similar legal and ethical questions. The UK government is considering authorizing the 'blind testing' of all patients to identify the AIDS virus. No individual may be identified in the tests and the information will be used only to establish the spread of infection. The disclosure was made last week by the government's chief medical officer, Sir Donald Acheson, in evidence to the House of Commons Social Services Select Committee.

He said: "It is being considered by ministers as a possibility. It would help us very much in planning and getting an idea of the prevalence and trends of the infection."

The plan has provoked much controversy. The British Medical Association supports the plan but the Medical Research Council, which this week will give evidence to the Commons committee, has raised doubts about the legality of such a strategy

Bill Johnstone

- Britain has increased its annual budget for treating AIDS from $£ 3$ million to $£ 7$ million; the major regional health authorities treating AIDS believe a figure of $£ 16$ million would be a more realistic estimate of what is needed.

\section{Peace attempt with university pay deal}

\section{London}

BRITAIN's university lecturers have been offered a two-year pay deal that will raise the average salary immediately by 16 per cent, backdated to last December, and by a further 7 per cent in March 1988. The figures are based on existing salary rates.

The executive is to meet this week to endorse or reject the offer although the negotiators have recommended its acceptance. About 47,000 academic staff and certain support stafis will be affected by the deal. The Association of University Teachers which had claimed 6 per cent, to be effective from last April, and 18 per cent from April this year, considers it the best deal under the circumstances.

According to Ms Diana Warwick, General Secretary of the AUT: "this offer is no remedy to recruitment and retention problems within our universities; it won't staunch the brain drain. There's been no pay increase in universities since 1985. It's clear that we have wrung out of the vicechancellors the best deal we could get, within the miserly terms allowed for by the Secretary of State."

The monies will come from the $£ 71 \mathrm{mil}$ lion of government funds allocated to the universities in a three-year plan - $\mathbf{\$ 4 0}$ million in 1987-88, $£ 16$ million in $1988-89$ and the remainder in 1989-90.

The AUT will open negotiations on a new claim in April 1988, just one month after the award of the second tranche. The union insist that the deal is a two-year agreement and must not be construed as running after March 1988.
Japanese X-ray satellite goes up successfully

Tokyo

JAPAN's X-ray astronomy satellite, Astro$C$, was successfully launched from the Kagoshima Space Center of the Institute of Space and Astronautical Science (ISAS) on 5 February. Developed jointly by Japanese, British and US scientists, the

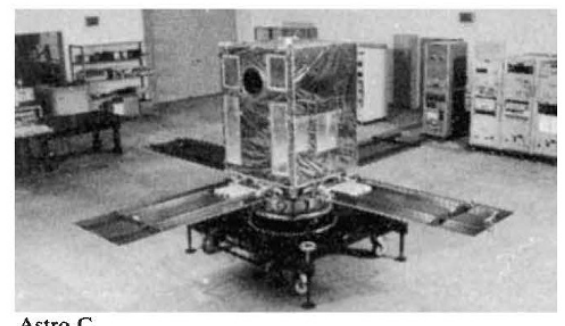

probe will monitor faint X-ray sources in the far reaches of the Universe.

The satellite, named Cinga (galaxy) in orbit, was carried aloft by a $28-\mathrm{m} \mathrm{M-3SII}$ solid-fuel rocket at 3.30 p.m. About $6 \mathrm{mi}-$ nutes later, the $420-\mathrm{kg}$ satellite entered low Earth orbit, and radio transmissions from the probe were picked up after it had completed its first loop around the Earth at an altitude of $500-600 \mathrm{~km}$.

Ginga, ISAS's third X-ray satellite, is the world's only operational X-ray probe following the demise of the European Space Agency's EXOSAT early last year. It carries eight identical large-area proportional counters, developed with groups at the University of Leicester and the Rutherford Appleton Laboratory in the United Kingdom, an all-sky X-ray monitor, and a gamma-ray burst detector, made in collaboration with a group at Los Alamos National Laboratory in the United States.

Collaboration between ISAS and the Leicester group stretches back seven years. Scientists have been exchanged under UK/Japan schemes for visiting scholars; the British side developed the hardware, Japan the electronics. Similar arrangements were made with the United States. The total cost of Ginga, including the MU-3SII rocket, is estimated at Y7,300 million (about $\$ 49$ million).

The highly sensitive, large-area detectors $\left(4,500 \mathrm{~cm}^{2}\right.$ in total) will be trained on distant X-ray sources, in particular quasars. The time-scale of X-ray fluctuations will give an indication of the size of the quasar nucleus and, according to Minoru Oda, director of ISAS, strong fluctuations would provide good evidence for the existence of a black hole in the centre of quasars that sucks in stars and interstellar material, releasing vast amounts of energy in the form of X-rays.

David Swinbanks 